\title{
AN APPROXIMATION PROPERTY OF POWER FUNCTIONS
}

\author{
SoOn-Mo Jung, YAng-Hi LeE And Ki Soo Kim
}

Abstract. We will solve the inhomogeneous linear first order differential equation of the form, $x y^{\prime}(x)+\lambda y(x)=\sum_{m=0}^{\infty} a_{m}(x-c)^{m}$, and prove an approximation property of power functions. More precisely, we prove the local Hyers-Ulam stability of linear first order differential equation, $x y^{\prime}(x)+\lambda y(x)=0$, in a special class of analytic functions.

Mathematics subject classification (2010): Primary 39B82, 41A30, secondary 34A30, 34A25, 34A05. Keywords and phrases: Linear first order differential equation, power series method, power function, approximation, Hyers-Ulam stability, local Hyers-Ulam stability.

\section{REFERENCES}

[1] C. Alsina AND R. GER, On some inequalities and stability results related to the exponential function, J. Inequal. Appl. 2 (1998), 373-380.

[2] S. CzERwiK, Functional Equations and Inequalities in Several Variables, World Sci. Publ., Singapore, 2002.

[3] P. GĂVRUȚA, S.-M. JUNG AND Y. LI, Hyers-Ulam stability for second-order linear differential equations with boundary conditions, Electron. J. Differential Equations 2011, 80 (2011), 1-5.

[4] D. H. Hyers, G. Is AC AND TH. M. RAssias, Stability of Functional Equations in Several Variables, Birkhäuser, Boston, 1998.

[5] S.-M. Jung, Legendre's differential equation and its Hyers-Ulam stability, Abst. Appl. Anal. 2007 (2007), Article ID 56419, 14 pages, doi: 10.1155/2007/56419.

[6] S.-M. Jung, Approximation of analytic functions by Hermite functions, Bull. Sci. math. (2007), doi: 10.1016/j.bulsci.2007.11.001.

[7] S.-M. JUnG, An approximation property of exponential functions, Acta Math. Hungar. 124, 1-2 (2009), 155-163.

[8] S.-M. Jung, Hyers-Ulam-Rassias Stability of Functional Equations in Nonlinear Analysis, Springer, New York, 2011.

[9] W. Kosmala, A Friendly Introduction to Analysis - Single and Multivariable (2nd edn), Pearson Prentice Hall, London, 2004.

[10] T. MiURA, S.-M. Jung AND S.-E. TAKAHASI, Hyers-Ulam-Rassias stability of the Banach space valued linear differential equations $y^{\prime}=\lambda y$, J. Korean Math. Soc. 41 (2004), 995-1005.

[11] M. OBŁOZA, Hyers stability of the linear differential equation, Rocznik Nauk.-Dydakt. Prace Mat. 13 (1993), 259-270.

[12] M. OBŁoza, Connections between Hyers and Lyapunov stability of the ordinary differential equations, Rocznik Nauk.-Dydakt. Prace Mat. 14 (1997), 141-146.

[13] M. H. Protter And C. B. Morrey, A First Course in Real Analysis (2nd edn), Springer, New York, 1991.

[14] S.-E. Takahasi, T. Miura And S. Miyajima, On the Hyers-Ulam stability of the Banach spacevalued differential equation $y^{\prime}=\lambda y$, Bull. Korean Math. Soc. 39 (2002), 309-315.

[15] W. R. WAdE, An Introduction to Analysis (2 nd edn), Prentice Hall, Upper Saddle River, NJ, 2000. 